JPH: Jurnal Pembaharuan Hukum

Volume 7, Number 1, April 2020

\title{
ADVOCATE ASSISTANCE AGAINST WITNESSES TOWARD THE SUSPECTED IN THE INVESTIGATION PROCESS OF CORRUPTION CRIMINAL ACT
}

\author{
Alamsyah Bahari \\ Pascasarjana Fakultas Hukum Universitas Indonesia \\ Alamsyahbahari027@gmail.com
}

\begin{abstract}
In order to create a good and transparent criminal justice process so that there is no imbalance between witnesses and law enforcement officials, advocate assistance to witnesses in the investigation process in cases of corruption is necessary because not everyone has mental readiness or knowledge regarding the law in the investigation process. This study aims to provide a complete and clear description of the procedure for examining witnesses who are accused in the process of investigating cases of corruption by authorized institutions and a description of the legal basis for anti-corruption institutions in implementing the prohibition on advocacy assistance to witnesses during the process of investigating criminal cases. corruption. The research method used by researchers is the normative juridical research method. The anomaly in the attitude of the investigator appears when the advocate accompanies a witness who is asked to present it by the reported party or the suspect. Before the examination, the investigator informs the witness that the presence of an Advocate in a witness examination is not obligatory. Advocate witness assistance should also be added to be strictly regulated in the regulations, to prevent unnecessary polemics on this matter. It also includes that the witness has the right to receive a copy of the examination report.
\end{abstract}

Keywords: Advocates, Corruption Crime, Legal Protection, Suspects, Witnesses.

\section{A. INTRODUCTION}

The Republic of Indonesia is a state based on law, the definition of a rule of law is commonly called the Rule of law. The concept of a rule of law or the universal rule of law relates to the recognition and protection of human rights, the legality of state / government actions in the sense of actions of state officials who can be accounted for legally and guaranteed free trial. ${ }^{1}$ The position of witnesses in the criminal justice process occupies a key position, as stated in Article 184 of the Criminal Procedure Code. As evidence, of course the impact can be felt if witnesses are not found in a case. The importance of the position of witnesses in the criminal justice process has started since the beginning of the criminal justice process. It must be admitted that the disclosure of cases of legal violations is mostly based on information from the

1 Edy O.S Hiarirj, Hukum Acara Pidana, Universitas Terbuka, South Tangerang, 2015, Page. 127

Jurnal Pembaharuan Hukum Volume 7 No.1 Januari - April 2020
ADVOCATE ASSISTANCE AGAINST WITNESSES TOWARD THE SUSPECTED IN THE INVESTIGATION PROCESS OF CORRUPTION CRIMINAL ACT Alamsyah Bahari 
public. $^{2}$ Article 1 point 26 of the Criminal Procedure Code explains the definition of witnesses, that a witness is a person who can provide information for the purposes of investigation, prosecution and trial regarding a criminal case which he has heard himself, has seen for himself, and experienced himself. ${ }^{3}$

In the provisions of the 1945 Constitution in Article 28D states that everyone has the right to recognition, guarantee, protection, and legal certainty that is just and treated equally before the law. Law No. 39/1999 on Human Rights (HAM) Article 18 paragraph (4) states that every person who is examined has the right to legal assistance from the time of investigation until a court decision has permanent legal force. Provisions for advocate assistance to witnesses are also contained in the investigation process at the Police, advocate assistance is regulated in the Chief of Police Regulation No. 8 of 2009 concerning the Implementation of Human Rights Principles and Standards in carrying out the Duties of the Indonesian National Police. Article 27 paragraph (1) point (a) states that the officer gives the opportunity to witnesses, suspects or investigators to contact and be accompanied by a lawyer before the examination begins. Article 27 paragraph 2 point a states that, "officers are prohibited from examining witnesses, suspects, or investigators before being accompanied by their legal advisers, except with the consent of the investigators. However, in practice this PERKAP also applies flexibly depending on the POLRI investigator. Unlike the Corruption Eradication Commission in practice, the investigation process at the Corruption Eradication Commission does not allow witnesses to be accompanied by lawyers.

Criminal Law Expert Prof. Romli Atmasasmita explained that lawyer assistance is the right of everyone involved in legal cases. ${ }^{4}$ According to him, anyone can be accompanied by a lawyer, if the KPK prohibits being accompanied by a lawyer, it is wrong. Because the Criminal Code is not prohibited, because it is the human right of everyone. In the Criminal Code, according to Prof. Romli Atmasasmita, it is stated that every suspect has the right to be accompanied by a lawyer during examination. Likewise with a witness there is also no prohibition on being accompanied by a lawyer. In the Criminal Code, the suspect has the right to be accompanied by a lawyer, but there is no rule whether a witness is allowed or not. ${ }^{5}$

2 Surastini Fitriasih, Perlindungan Saksi Dan Korban Sebagai Sarana Menuju Proses Peradilan (Pidana) Yang Jujur Dan Adil, http/www.antikorupsi.org/mod=tema\&op=viewarticle\&artid, accessed on date 22 April 2018.

3 Ibid.

4 Sri Endah Wahyuningsih and Agus Sunaryo, The Role of Prosecutor Office In The Eradication Of Corruption Criminal Acts in Indonesia. Jurnal Pembaharuan Hukum, Volume IV, Issue 2, Agustus 2017, Page.245

5 http://www.jurnas.com.artikel/20806/KPK-Keliru-Larang-Saksi-dan-Tersangka-DidampingiPengacara/, accessed on date16 April 2018. 
The same opinion was expressed by the criminal law expert Chairul Huda, he emphasized that investigations by KPK investigators were forbidden using pressure and violence. In order to avoid accusations of pressure from investigators to witnesses, according to the rules in Article 117 Paragraph (1) of the Criminal Procedure Code stipulates that witnesses testify freely without pressure, therefore Chairul Huda suggested that the KPK allow witnesses to be accompanied by a lawyer while undergoing the examination process. ${ }^{6}$

If you look at the protection of witnesses in Germany it is regulated in two laws, namely the German Criminal Procedure Code (Strafprozessordnung / StPO). ${ }^{7}$ In 1998 there was a special amendment to the issue of witness protection through the Act on Witness Protection in the Process of Criminal Examination and Protection of Victims (Zeugenschutzgesetz / ZschG) the implementation of witness protection is subject to the authority of each German state. In connection with that, in 2001 the German government passed the Harmonization Law for Witness Protection. in Danger (Zeugenschutzerungsgesetz / ZshG). ${ }^{8}$ This law only regulates general witness protection. In this law there is no distinction between witnesses and victim witnesses. Furthermore, this law does not regulate the protection of witnesses who are whistle-blowers..

The right of a witness to be accompanied, a witness who cannot give his testimony alone, with the approval of the Public Prosecutor's Office, can be accompanied by a lawyer (Article $68 \mathrm{~b}$ ZschG). The conditions that must be met to get a lawyer are that the witness cannot face a very difficult and difficult legal situation, and if there is a danger that must be faced, he cannot possibly face the danger without a lawyer. Costs incurred in obtaining a lawyer for non-victim witnesses will be borne by the defendant (if proven guilty) or borne by the state. As stipulated in Articles 465, 464 (a) StPO. Meanwhile, legal fees for victim witnesses are borne personally (Article $406 \mathrm{f}$ KUHAP Germany Strafprozessordnung (StPO). ${ }^{9}$

The Corruption Eradication Commission (KPK) has the authority to determine the status of a witness as a suspect. One of the duties of the KPK based on Article 6 letter c of Law Number 30 of 2002 concerning the Corruption Eradication Commission is to carry out investigations, investigations and prosecutions of criminal acts of corruption. In practice, someone who is initially only a witness in a case can be prosecuted as a suspect in the same

6 https://www.kricom.id/hindari-tudingan-intimidasi-kpk-harus-perbolehkan-saksi-didampingipengacara/feed/, diakses tanggal 16 April 2018.

7 Strafprozessordnung yang selanjutnya disingkat StPO merupakan hukum yang mengatus Prosedur acara peradilan pidana di jerman, atau KUHAP di Indonesia.

8 Zeugenschutzharmonisierungsgesetz atau disebut dengan ZshG merupakan Undang-undang yang mengatur harmonisasi dari perundang-undangan negara bagian tentang perlindungan terhadap Saksi.

9 Viktor K Pesik,Kewenangan KPK Dalam Pemberantasan Tindak Pidana Korupsi. Lex Et Societatis, Volume II, Issue 6, July 2014, Page.105 
case but on a new file. For example, Hari Sabarno, who acted as a witness in the Oentarto Sindung Mawardi corruption case regarding the procurement of a fire engine, eventually became a suspect. Advocate assistance to witnesses in the investigation process at the KPK is necessary because not everyone has mental readiness or knowledge regarding the law in the investigation process at the KPK. For the realization of a good judicial process, it requires an active role from advocates to protect people who need legal assistance. Based on the description of the above problems, the researcher is interested in conducting a research entitled advocate assistance to witnesses who were made suspects in the investigation process at the Corruption Eradication Commission (KPK). ${ }^{10}$

The researcher used the Normative Juridical research method with 3 (three) approaches to study the two problems discussed with this Normative research method, namely the statute approach and the conceptual approach. A statutory approach is needed in order to trace the ratio legis and ontological basis for the creation of legislation. ${ }^{11}$ The conceptual approach is used to understand precisely and accurately the various concepts used by legal principles in the laws and doctrines of jurists. Sources of data used in research are secondary data consisting of primary legal materials in the form of statutory regulations and secondary legal materials in the form of literature and research results. The laws and regulations used are Law Number 31 of 1999 jo. Law Number 20 of 2001 concerning the Eradication of Corruption Crime, Criminal Procedure Code.

The purpose of this study is to provide a complete and clear description of the procedure for examining witnesses who are accused in the investigation of corruption cases by the competent institution. In addition, this study also aims to explain the legal basis for anti-corruption institutions in implementing the prohibition on advocacy assistance to witnesses during the process of investigating corruption cases.

\section{B. DISCUSSION}

\section{EXAMINATION OF WITNESSES WHO PROPOSED IN THE INVESTIGATION PROCESS AT THE KPK WITH ADVOCATES}

In principle, the determination of a person to be a suspect is carried out through an act of investigation. Based on Article 1 number 2 of Law No. 8 of 1981 concerning Criminal Procedure Law (KUHAP), an investigation is a series of actions by an investigator in terms and according to the manner stipulated in the Criminal Procedure Code to seek and collect evidence which with that evidence sheds light on the criminal act that has occurred and in order to find the suspect. ${ }^{12}$ So, the determination of the suspect lies with the investigator.

10 Ibid.

11 Peter Mahmud Marzuki, Penelitian Hukum, Kencana, Jakarta, 2014, Page. 93-94

12 Law No. 8 of 1981 concerning Criminal Procedure Law (KUHAP), 
Basically, the status of a suspect can be applied to a person who is suspected of committing a criminal act. It could be that previously the person concerned was a witness. Supreme Court Decision No. 205K / Kr / 1957 dated 12 October 1957 stated that to determine who would be charged with committing a crime was solely borne by the public prosecutor. ${ }^{13}$ However, in the courtroom, it is the judge who has the most power, including in sorting out which witnesses should be questioned. ${ }^{14}$ Furthermore, in Article 66 paragraph (1) and paragraph (2) Chief of Police Regulation No. 12 of 2009 Supervision and Control of Criminal Case Handling within the Indonesian National Police (Perkap 12/2009) states that:

a. The investigator's status as a suspect can only be determined by a person after the results of the investigation carried out have obtained sufficient initial evidence, namely at least 2 (two) types of evidence.

b. (2) To determine whether to obtain sufficient preliminary evidence, namely at least 2 (two) types of evidence as referred to in paragraph (1) shall be determined through a case title..

Whereas in order to determine a person to be a suspect, sufficient initial evidence must be found, namely at least 2 (two) types of evidence, and determined by means of pekara title. So there must be a process in advance of determining someone to be a suspect. Based on Article 1 figure 11 jo. Article 14 paragraph (1) Perkap 12/2009, procedure for case settlement including investigation and determination of suspects, must be carried out in a professional, proportional and transparent manner so that there is no abuse of authority and furthermore, it does not merely have the tendency to make someone a suspect.

In practice, the KPK in conducting an investigation can increase the status of a person who is initially only a witness in a case, who can be prosecuted as a suspect in the same case but a new file. ${ }^{15}$ Adnan Paslyadja, criminal law expert, explained about the process of determining a suspect. Adnan said that investigators must have at least 2 sufficient pieces of evidence in accordance with Article 44 of the KPK Law. If the 2 pieces of evidence are obtained at the final stage of the investigation, according to Adnan, the suspect can be determined. ${ }^{16}$ The 'juridical' argument that is often put forward by investigators, both the KPK and the Police, that the Criminal Procedure Code does not regulate the assistance of witnesses by advocates is thus not correct. Indeed, if the Criminal

13 Supreme Court Decision No. 205K / Kr / 1957

14 Look in SEMA No. 2 of 1985 concerning the Selection of Witnesses Ordered to Appear in Court Session).

15 http://www.hukumonline.com/klinik/detail/lt53608673190e8/siapa-saja-yang-berwenangmenetapkan-saksi-menjadi-tersangka, accessed on date 16 Mei 2018.

16 https://news.detik.com/berita/d-3660861/ahli-kpk-jelaskan-soal-penetapan-tersangka-dipenyelidikan, accessed on date 16 Mei 2018. 
Procedure Code is read partially between articles, the argumentation can be justified. On the other hand, if it is read using clear common sense, understanding of procedural law and a comprehensive criminal justice system, as well as the correct paradigm regarding the existence of witnesses, then the argumentation is of course wrong. You don't have to go far from fighting over the provisions of the law. Using common sense alone, let us ask: "Are the witnesses worse or inferior to the suspected perpetrators of terrorism, so they are not entitled to legal advice from an advocate. If a suspect who is suspected of committing a criminal act has the right to even choose his legal adviser, let alone a witness who in fact is a free person and often ordinary people who hear the words "police" and "police station" are still often afraid, let alone the sentence " police".

If then there is another logical fallacy which says: why be accompanied by an advocate, yet the witness only tells what he saw, heard and experienced for himself. We can answer such questions briefly if the investigator is as fair as God, then at the same time the suspect does not need to be accompanied by an advocate and all judges are free to assign them. As we know, it is an important principle in a modern legal state that a person affected by a case has the right to obtain legal assistance.. ${ }^{17}$

\section{KPK DOES NOT ALLOW ADVOCATES TO ASSIST WITNESSES IN THE INVESTIGATION PROCESS}

Like a house, a witness is the key to entering a case hole. The information becomes important in the process of proving the law. Not only for investigators, prosecutors and judges, but also suspects and defendants. Not only revealing the details of facts and reconstructing events, but also new facts. The statements can weaken the charges, allegations, or even strengthen the allegations and charges, including later the severity of the verdict of a case.

The word "witness" in KUHAP is scattered in many articles. To get a correct and clear definition of the witness's conception as a whole, we need to first read and pay attention to all of these articles. ${ }^{18}$ What is often forgotten is that in this country a person who is examined as a witness, not long after that without any notification, is changed his status to a suspect by investigators, then summoned again to be examined as a suspect. This

17 The Basic Law of Judicial Power , Article 35 of Law no. 14 of 1970

18 The Constitutional Court (MK) itself is currently examining two cases containing the examination of several articles in law number 8 of 1981 against the Constitution related to the issue of witnesses. The two petitions - Case number 28 / PUU-VIII / 2010 filed by Rino Pandairot, et al, and case number 65 / PUU-VIII / 2010 filed by Yusril Ihza Mahendra as a petitioner - stated that the provisions of Article 1 number 26 and number 27, Article 65, Article 116 paragraph (3), paragraph (4), and Article 184 paragraph (1) of the Criminal Procedure Code are deemed to have negated the recognition of guaranteed protection and legal certainty and are considered contrary to the principles of the rule of law and the constitution. 
is clearly detrimental to the legal rights of a witness. In such a context, the presence of an Advocate is crucial, it can help witnesses not to fall into trapping questions, which then trap the witness. Tricking questions that have the tendency to hook confessions clearly violate the principle that one cannot be forced to admit wrongdoing.

Yahya Harahap as a Former Chief Justice once wrote his complaint regarding the issue of witness testimony from YAITU's investigation regarding the extent and quality of the required witness testimony, the method of examination must be tested on a legal basis, so that in seeking and directing witness testimony during examination, it is truly aimed at urgency. in accordance with the desired provisions of the law itself. Not going off in an irrelevant direction. But it is exactly within the scope required by the legal provisions. Sometimes out of the tens of witnesses examined by investigators, none of them hit the standards determined by law. The witness testimony in the minutes, none of which explains the source of his knowledge .... Therefore, investigators must selectively choose to examine witnesses whose weight is in accordance with determined legal basis standards who are deemed eligible as witness testimony which can be of value as evidence .

Yahya Harahap's complaint arose because of the absence of advocate assistance. If the Advocate is there, the investigator does not need to bother asking many questions, because the Advocate may object that the presence of a witness is irrelevant in the case being examined and the investigator's question has no connection with the case. The writer understands, especially in the Police, that often an investigator does not have a law degree who is educated to understand the concept of law only with habit alone. If someone who has the status of a suspect has such a large amount of rights, isn't it then very strange if a witness is prohibited from having the same right in terms of voting in the presence of an Advocate. ${ }^{19}$

Based on Article 1 number 26 KUHAP, Article 1 number 27 KUHAP, Article 65 KUHAP, Article 116 paragraph (3) KUHAP, Article 116 paragraph (4) KUHAP, and Article 184 paragraph (1) letter (a) KUHAP, then we can find the definition of a witness as conveyed by Prof. Eddy OS Hiariej, namely a person who provides information, for the purposes of investigation, prosecution, trial regarding a criminal case which he has heard himself, he has seen himself, experienced himself, is also a person who can provide information relating to a criminal case even though he has not heard it himself, he has not seen it himself, and he has not experienced it himself, as long as the testimony of that person according to the judgment of the suspect and / or the defendant is related to a criminal act

19 Yahya Harahap, Op. Cit., Page. 41 
which is suspected and or charged to him will be beneficial and / or mitigate for him. ${ }^{20}$

In the investigation / investigation stage as part of the pre-judicial stage, witnesses can play a role in determining whether a criminal case has actually occurred or not. Witnesses also play a role in determining the legal status of a person, who was originally in a free state, then changed his status to become a suspect for whom forced legal action can be taken under the law. Due to the importance of the presence of witnesses, the Criminal Procedure Code then regulates that summons as witnesses are a legal obligation that must be fulfilled and for those who wish to renounce this obligation, investigators have the authority to carry out forced legal remedies in the form of bringing / picking up witnesses by force. ${ }^{21}$

The thing that raises the question of why a witness can become a suspect is whether there was manipulation by the investigator to make the witness a suspect or a suspect. ${ }^{22}$ In Indonesia, a witness does not have to be accompanied by an advocate, but what makes this matter must be accompanied by an advocate because sometimes he was summoned as a witness and when he left he was already named a suspect. The urgency of the presence of witnesses in criminal proceedings can also be seen from the minimal differences between the examination of witnesses and suspects, both regarding the procedures for summoning and regarding the procedures for examination. Even the regulation is regulated in the same articles, not separated into different article rules. There are several important matters regarding the procedure for examination as a witness in the Criminal Procedure Code, as follows: ${ }^{23}$

a. In providing information to investigators, it must be free from all kinds of pressure, whether in any form or from anyone.

b. Witnesses can be examined at their place of residence, in the event that the witness is unable to fulfill the summons to appear at the place of examination determined by the investigator due to proper and reasonable reasons..

c. Witnesses are examined without oath, except before a trial.

d. The information presented by the witness during the investigative examination shall be carefully recorded by the investigator in the examination report. The minutes are signed by the witnesses but the

20 Article 1 number 26 of KUHAP

21 http://www.hukumonline.com/berita/baca/lt4dde135c2e3a4/urgensi-pendampingan-saksi-olehadvokat-broleh--bobby-r-manalu-, accessed on date 16 Mei 2018.

22 Bambang Sunoto and Jawade Hafidz,Pendampingan Penasihat Hukum Terhadap Tersangka dan Terdakwa Dalam Perkara Korupsi (Studi Kasus Wilayah Hukum Pengadilan Tindak Pidana Korupsi Semarang), Jurnal Hukum Khaira Ummah, Volume 13, No. 1, March 2018, Page.303

23 Yahya Harahap, Pembahasan Permasalahan dan Penerapan KUHAP, Penyidikan dan Penuntutan, Sinar Grafika, 2000, Jakarta, P. 138-140 
witnesses are given the possibility not to sign the minutes of examination by providing strong reasons.

Advocates are not allowed to accompany their clients who are witnesses while undergoing the examination or investigation process. The KPK imitates the steps of the Police which also prohibits an Advocate from accompanying his client when being examined as a witness, although sometimes it softens a little, Advocates are allowed to accompany their clients, but only in terms of listening to the proceedings of the examination. If the Advocate makes many comments, the address of the order for eviction from the examination room will be received immediately. The reasons vary from KPK investigators, namely because the Criminal Procedure Code does not require this. Apart from normative reasons like that, the reason that is often cited is because if they are allowed to accompany, Advocates often interfere with the proceedings of the examination. It was not explained in more detail what the form of the disturbance was. What is meant by disturbing is that the Advocate tries to slow down the investigation process because every time there is a question from the investigator, the Advocate protests. Or the disturbance means that the advocate tries to influence his client to give convoluted and unclear information.

In principle, everyone can be a witness, but against a person with a certain status, the law provides an opportunity for those who are called as witnesses to resign or be exempted from this obligation. The investigator shall summon witnesses by sending a "summons" stating the reasons for the summons clearly and observing a reasonable grace period. ${ }^{24}$ The presence of advocates will be able to prevent investigators from committing acts of violence both physically and psychologically against witnesses. The witness also felt safer and more comfortable in giving information because he was accompanied by someone who understood the legal process. Advocates can help witnesses understand the questions raised by investigators, because often the investigators' questions are vague, sometimes very technical and difficult for witnesses to understand. ${ }^{25}$ Advocates in witness examination can be used as partners in a fast, effective and efficient law enforcement framework. Regarding the argument that the presence of Advocates often has an effect that is able to mislead witness statements, this also cannot be used as an excuse. Maybe in reality there are some Advocates who act in this way, but this cannot be used as a justification for prohibiting Advocates from attending the witness examination.

24 Article 112 of KUHAP

25 Herning Setyowati, and Nurul Muchiningtias, Peran Advokat Dalam Memberikan Bantuan Hukum Kepada Masyarakat Dalam Perspektif Hak Asasi Manusia, Lex Scientian Law Review, Volume 2, No. 2, November 2018, Page.162 
Advocates have the status of law enforcers, just like investigators. In carrying out their work, Advocates are prohibited from behaving, behaving, speaking words, or issuing statements that show disrespect for the law, laws and regulations. Advocates are also prohibited from doing things that are contrary to their obligations, honor, or professional dignity. Advocates are obliged not to violate laws and regulations and / or act disgraceful; violates the Advocate's oath / promise and / or the Advocate's professional code of ethics. Thus, there should be no prohibition against an Advocate from accompanying someone being examined as a witness. ${ }^{26}$

\section{CONCLUSION}

In practice, the author believes that investigators are often ambivalent about the presence of a witness. If the witness is the reporter, often only with a power of attorney, the Advocate without being accompanied by the principal is allowed to report. When witnesses act as reporters who often have the status of victims, Advocates are often allowed to attend. Not only are they present, Advocates often work together with investigators to conduct legal analysis whether the report submitted by the witness meets the elements of a criminal act. Almost never there has been a denial of the presence of an Advocate in such a condition. The anomaly in the attitude of the investigators can only be seen when the Advocate accompanies a witness who is asked to present him by the reported party or the suspect. Prior to the examination, the investigator had not yet directly conveyed to the witness that in the criminal procedure code, the existence of an Advocate in a witness examination was not obligatory. Isn't the criminal law process a search for material truth? Isn't it necessary to maintain the principle of "presumption of innocence" in the investigation process so that witnesses presented by the suspect also have the right to be treated the same? The investigator either forgot or pretended not to know that under the Witness and Victim Protection Law every witness has the right to get legal advice from an Advocate. In the future, witness assistance by advocates should also be added to be strictly regulated, to prevent unnecessary polemics on this matter. It also includes that the witness has the right to receive a copy of the examination report. One solution related to this writing is that lawyers can see through the mirror and cannot hear conversations from investigators and witnesses. However, this actually has a weakness because investigators may intervene or trap witnesses so that they become suspects.

26 Article 5 and Article 6 of Law no. 18 of 2003 concerning Advocates 


\section{BIBLIOGRAPHY}

\section{Books :}

Kelsen, Hans, 1961, General Theory of Law and State. Translated by: Anders Wedberg, Russell \& Russel,New York;

Marzuki, Peter Mahmud, 2014, Penelitian Hukum, Kencana, Jakarta;

Wasserman, Rhonda. Procedural Due Process: A Reference Guide to the United States Constitution, Greenwood Publishing Group, Connecticut;

Harahap Yahya, 2000, Pembahasan Permasalahan dan Penerapan KUHAP, Penyidikan dan Penuntutan, Sinar Grafika, Jakarta;

Hiarirj Edy O.S, 2015, Hukum Acara Pidana, Universitas Terbuka, Tangerang Selatan;

Surastini Fitriasih, Perlindungan Saksi Dan Korban Sebagai Sarana Menuju Proses Peradilan (Pidana) Yang Jujur Dan Adil, http/www. antikorupsi. org/mod =tema \& op = view article \&artid, diakses tanggal 22 april 2018.

\section{Journals:}

Bambang Sunoto and Jawade Hafidz, 2018, Pendampingan Penasihat Hukum Terhadap Tersangka dan Terdakwa Dalam Perkara Korupsi (Studi Kasus Wilayah Hukum Pengadilan Tindak Pidana Korupsi Semarang), Jurnal Hukum Khaira Ummah, Volume 13, No. 1, March 2018.

Herning Setyowati, 2018, and Nurul Muchiningtias, Peran Advokat Dalam Memberikan Bantuan Hukum Kepada Masyarakat Dalam Perspektif Hak Asasi Manusia, Lex Scientian Law Review, Volume 2, No. 2, November 2018.

Sri Endah Wahyuningsih and Agus Sunaryo, 2017, The Role of Prosecutor Office In The Eradication Of Corruption Criminal Acts in Indonesia, Jurnal Pembaharuan Hukum, Volume IV, Issue 2, Agustus 2017.

Suratno, 2017, Perlindungan Hukum Saksi dan Korban Sebagai Whistleblower dan Justice Collaborators pada Pengungkapan Kasus Korupsi Berbasis Nilai Keadilan, Jurnal Pembaharuan Hukum , Volume IV, Issue 1, April 2017.

Viktor K Pesik, Kewenangan KPK Dalam Pemberantasan Tindak Pidana Korupsi, Lex Et Societatis, Volume II, Issue 6, July 2014.

\section{Legislation :}

Indonesia. 1945 Constitution

Indonesia. Law No. 8 of 1981 concerning Criminal Procedure Law

Indonesia. Law No. 39 of 1999 on Human Rights (HAM) 
Indonesia. Law Number 30 of 2002 concerning the Corruption Eradication Commission.

Indonesia. Law No.13 of 2006 concerning Witness and Victim Protection.

Indonesia. Law No. 18 of 2003 concerning Advocates

Indonesia. Chief of Police Regulation No. 8 of 2009 concerning the Implementation of Human Rights Principles and Standards in carrying out the Duties of the Indonesian National Police.

Website :

http://www.hukumonline.com/klinik/detail/tt53608673190e8/siapa-saja-yangberwenang-menetapkan-saksi-menjadi-tersangka, accessed on date 22nd April 2018.

http://www.jurnas.com/artikel/20806/KPK-Keliru-Larang-Saksi-dan-TersangkaDidampingi-Pengacara/, accessed on date 16th April 2018.

https://www.kricom.id/hindari-tudingan-intimidasi-kpk-harus-perbolehkan-saksididampingi-pengacara/feed/, accessed on date 16th April 2018.

http://www.jurnas.com/artikel/20806/KPK-Keliru-Larang-Saksi-dan-TersangkaDidampingi-Pengacara/, accessed on date 16th April 2018

https://www.kricom.id/hindari-tudingan-intimidasi-kpk-harus-perbolehkan-saksididampingi-pengacara/feed/, accessed on date $16^{\text {th }}$ April 2018 